\title{
Effect of diet on disaccharidase activity in the chick
}

\author{
By R. C. SIDDONS* \\ National Institute for Research in Dairying, Shinfield, Reading RG2 ${ }_{9} A T$
}

(Received 6 April 1971 - Accepted I7 September 1971)

\begin{abstract}
I. The influence of diet, particularly dietary carbohydrate, on the development of the intestinal disaccharidases of the chick was studied.

2. The maltase activity in the small intestine was similar in groups of 25 -d-old chicks that had been fed, from hatching, on diets containing either starch, glucose, maltose, sucrose, or a mixture of $50 \%$ glucose $+50 \%$ lactose, as the source of carbohydrate. The sucrase activity in the small intestine was also similar in the different groups, as was the palatinase (the enzyme that hydrolyses palatinose, i.e. 6-0- $\alpha$-D-glucopyranosyl-D-fructose) activity. The maltase activity in the large intestine of the group receiving the starch-containing diet was significantly increased. The lactase activity in the large intestine was significantly higher in the group receiving the $50 \%$ glucose $+50 \%$ lactose and in the group receiving glucose than in the other groups. Body-weights were similar with all the diets.

3. The fasting of chicks for a period of $3 \mathrm{~d}$ caused a marked decrease in the activity of the disaccharidases and in the protein content of the homogenates of the small intestine.

4. The maltase activity was similar in the small intestine of chicks that had been fasted for $3 \mathrm{~d}$ and subsequently given diets containing either starch, glucose, maltose, sucrose or fructose for $5 \mathrm{~d}$. The sucrase activity, the isomaltase activity and the palatinase activity were also similar in the small intestine of the chicks given the different diets. Feeding with a fat-free or protein-free diet did not affect the development of disaccharidases in the small intestine, but feeding with a carbohydrate-free diet resulted in reduced disaccharidase activity.

5. The results suggest that, in the chick, dietary carbohydrate is necessary for the development of the disaccharidases but the form of the carbohydrate is not important. None of the sugars tested had a specific effect on a particular disaccharidase.
\end{abstract}

Disaccharides are not readily absorbed from the small intestine and therefore the intestinal disaccharidases play an important part in the utilization of dietary carbohydrate. In most newborn mammals lactase activity is high and maltase and sucrase activities are low. Subsequently the lactase activity decreases, and on weaning there is a marked increase in maltase and sucrase activities (Alvarez \& Sas, I96I; Doell \& Kretchmer, r962; Rubino, Zimbalatti \& Auricchio, I964; Welsh \& Walker, I965).

Most of the studies designed to determine whether the activities of the disaccharidases increase in response to a particular dietary carbohydrate have concentrated on the effect of dietary lactose on lactase activity. In general, no adaptive increase in the lactase activity has been observed (Cuatrecasas, Lockwood \& Caldwell, I965; Keusch, Troncale, Thavaramara, Prinyanont, Anderson \& Bhamarapravathi, 1969; Bayless \& Huang, I969). However, Bolin, Pirola \& Davis (1969) have reported higher lactase activities in the small intestines of rats given lactose rather than starch. The feeding of maltose to rats caused a specific increase in maltase activity, and similarly sucrose increased sucrase activity (Deren, Broitman \& Zamcheck, I967; Reddy, Pleasants \&

* Present address: The Wellcome Trust Research Laboratories, PO Box 3640, Nairobi, Kenya. Requests for reprints to be sent to The Nutrition Department, NIRD, Shinfield, Reading, RGz $9 A T$. 
Wostmann, I968). In man, feeding with either sucrose or fructose gave greater increases in maltase and sucrase activities than feeding with other sugars (Rosensweig \& Herman, $1968 a$ ).

In many respects, the disaccharidases in the small intestine of the chick are similar to the corresponding enzymes in the weaned mammal (Siddons, 1969, 1970). It was decided therefore to study the effect of dietary carbohydrate on the development of these enzymes. The findings suggest that, though dietary carbohydrate is necessary for the development of the disaccharidases, the effect is independent of the form of the carbohydrate.

\section{EXPERIMENTAL}

Chicks. Light Sussex $\times$ Rhode Island Red chicks were used. In each experiment roughly equal numbers of male and female chicks were assigned to each treatment. They were housed in electrically heated tier brooders.

Diet. The composition of the basal diet is given in 'Table $\mathrm{I}$. In the 'standard diet' the carbohydrate was maize starch. The other diets used in this study were prepared by replacing the maize starch with different specified carbohydrates or by leaving out either the maize starch in the carbohydrate-free diet, the casein in the protein-free diet or the maize oil in the fat-free diet. Food and water were given $a d$ lib.

\section{Table r. Composition ( $g / \mathrm{r} \circ 0 \mathrm{~g})$ of the basal chick diet}

$\begin{array}{lc}\text { Carbohydrate* } & 59.65 \\ \text { Casein } & 18.0 \\ \text { Gelatin } & 10.0 \\ \text { Salt mixturet } & 6.0 \\ \text { L-Cystine } & 0.3 \\ \text { Choline chloride } & 0.15 \\ \text { Inositol } & 0.10 \\ \text { Vitamin trituratet } & 0.80 \\ \text { Maize oil } & 5.0\end{array}$

* In the 'standard diet' (SCG) the carbohydrate was maize starch. In other diets the carbohydrate was one of several different mono- and di-saccharides.

$\uparrow$ Provided (per roog diet): $\mathrm{CaCO}_{3} \mathrm{I} \cdot 7 \mathrm{I} \mathrm{g} ; \mathrm{CaHPO}_{4} \cdot 2 \mathrm{H}_{2} \mathrm{O}$ I*7I g; $\mathrm{KH}_{2} \mathrm{PO}_{4} \mathrm{I} \cdot 33 \mathrm{~g} ; \mathrm{NaCl} 867 \mathrm{mg}$; $\mathrm{MgSO}_{4} \cdot \mathrm{H}_{2} \mathrm{O} 267 \mathrm{mg} ; \mathrm{FeSO}_{4} \cdot \mathrm{H}_{2} \mathrm{O} 67 \mathrm{mg} ; \mathrm{MnSO}_{4} \cdot 4 \mathrm{H}_{2} \mathrm{O} 27 \mathrm{mg} ; \mathrm{ZnSO}_{4} \cdot{ }_{7} \mathrm{H}_{2} \mathrm{O} \mathrm{r}_{3} \mathrm{mg} ; \mathrm{KI} 3.7 \mathrm{mg}$; $\mathrm{CuSO}_{4} \cdot 5 \mathrm{H}_{2} \mathrm{O}$ I. 6 ing.

† Provided (per roog diet): biotin $80 \mu \mathrm{g}$; folic acid $600 \mu \mathrm{g}$; thiamin $\mathrm{I} \cdot 2 \mathrm{mg}$; pyridoxine $\mathrm{I} \cdot 6 \mathrm{mg}$; riboflavin $2.4 \mathrm{mg}$; calcium pantothenate $6.0 \mu \mathrm{g}$; nicotinic acid $16 \mathrm{mg}$; cyanocobalamin $8 \mu \mathrm{g}$; retinyl acetate $6800 \mathrm{i}, \mathrm{u}$.; menaphthone $2 \mathrm{mg}$; $\alpha$-tocopheryl acetate $5 \mathrm{mg}$; cholecalciferol 640 i.u.

Preparation of homogenates. The method for preparing the intestinal homogenates has been described previously (Siddons, 1969). The chicks were fasted overnight before preparing the homogenates; the results refer to the activity in the intestinal wall plus contents.

Measurement of disaccharidase activity. The disaccharidase activities were determined by the method of Dahlqvist (1964). Maltase activity was assayed at $\mathrm{pH} 5 \cdot 8$, sucrase and palatinase (the enzyme that hydrolyses palatinose, i.e. $6-0-\alpha-\mathrm{D}-$ glucopyranosyl-D-fructose) at $\mathrm{pH} .6 \cdot 2$, isomaltase at $\mathrm{pH} 6 \cdot 4$ and lactase at $\mathrm{pH} 5 \cdot 6$. A substrate concentration of $28 \mathrm{~mm}$ in $50 \mathrm{mM}$-sodium malcate buffer was used in all the 
assays except in those of isomaltase when for cconomy a concentration of $2.8 \mathrm{mM}$ was used. One unit of disaccharidase activity is defined as the amount that hydrolyses I $\mu \mathrm{mol}$ disaccharide in $60 \mathrm{~min}$ at $37^{\circ}$.

Determination of protein. The protein content of the homogenates was assayed by the method of Lowry, Rosebrough, Farr \& Randall (195 I). Bovine plasma albumin was used to prepare a standard curve.

Plan of experiments. Expt I was designed to determine whether the form of dietary carbohydrate had any effect on growth and intestinal disaccharidase activity. For this purpose I-d-old chicks were randomly divided into groups of ten and assigned to diets in which the carbohydrate was supplied as starch, glucose, maltose or sucrose or as a mixture of $50 \%$ glucose and $50 \%$ lactose. The ten chicks on a diet were housed in one cage. The chicks received the diets ad $7 i b$. for $24 \mathrm{~d}$. They were then starved overnight, weighed and killed, and the disaccharidase activities were measured.

In Expt 2 the effect of fasting on the disaccharidase activity in the small intestine was studicd. Food was withheld from three groups of five I6-d-old chicks for $24 \mathrm{~h}$,

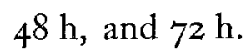

As Expt 2 showed that during a $3 \mathrm{~d}$ fasting period there was a decrease in the disaccharidase activities, it was hoped that during a refeeding period there would be a rapid development of disaccharidase activity when the effect, if any, of a particular diet would be more apparent. Therefore, in Expt 3 a comparison was made of the disaccharidase activities in the small intestine of groups of five or six chicks which had been fasted for $3 \mathrm{~d}$ and then fed on different diets for $5 \mathrm{~d}$. Two flocks of birds were used. Three birds from each flock were allocated at random to a treatment and all receiving the same diet were housed in a single cage.

Statistical analysis. In Expt I the standard errors were based on differences between chicks within diets. In Expt 3 the standard errors were calculated using the interaction between treatments and flocks. The tests of significance given in the tables are based on Duncan's multiple range test. Any differences which may exist between cages cannot be allowed for in the analysis, since all the birds that received a diet or treatment were in the same cage.

\section{RESULTS}

\section{Expt I}

The mean values for the body-weights of the birds on the different diets are recorded in Table 2: there were no significant differences between the groups. The weight of the small intestine plus contents was also similar in chicks on all diets, but the length in chicks on the diet containing lactose was increased significantly. This diet also caused a twofold increase in the weight of the large intestine compared with the other diets.

At the end of the cxperiment the overall diet efficiency (weight gained $(\mathrm{g})) /($ diet consumed $(\mathrm{g})$ ) of the various diets was calculated. For the diets containing starch, sucrose, maltose or glucose the values were similar, being $0.517,0.510,0.546$ and 0.598 respectively. On the diet containing lactose the value was 0.399 , which indicates that on this diet more food may be needed for growth. 


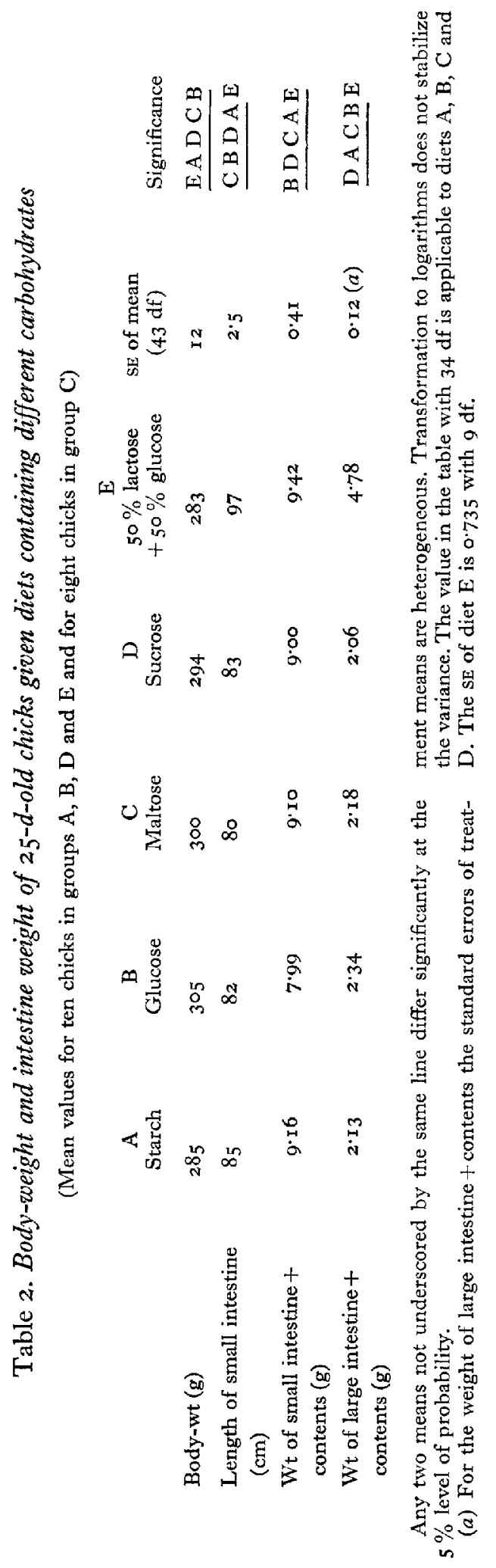


(⿸丆口

$\frac{\sqrt{2}}{8}$

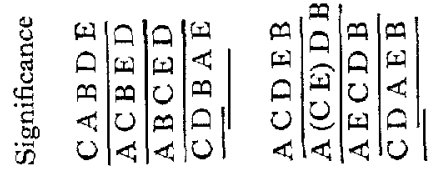

है

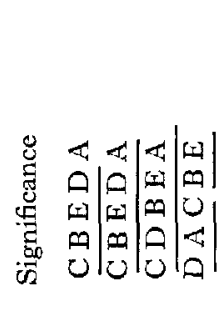

$\stackrel{\circ}{\overrightarrow{3}}$

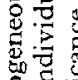

의

בัँ

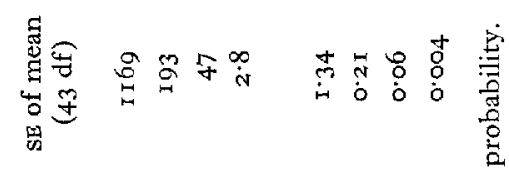

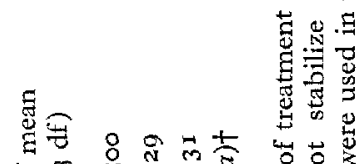

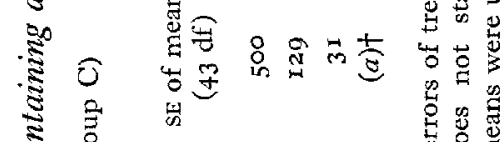

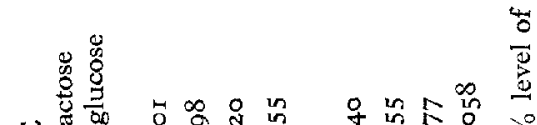

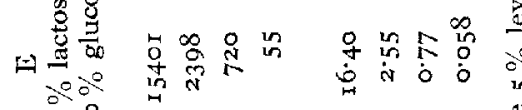

in in

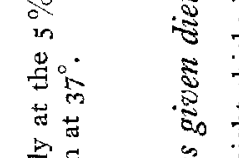

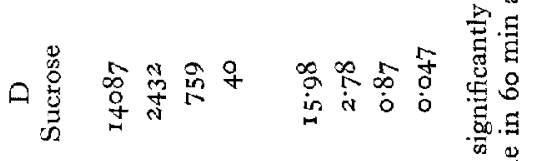

离

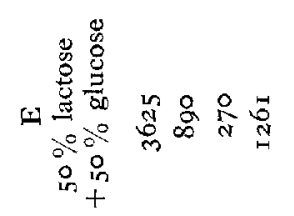

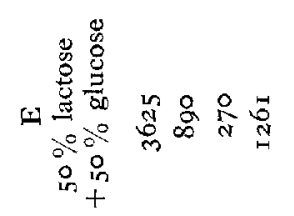

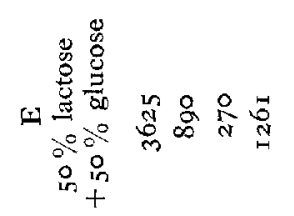

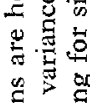

过

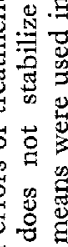

密要

का

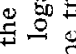

密

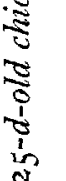

它定

.

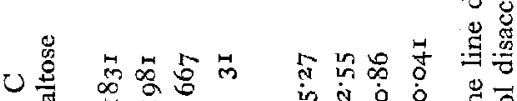

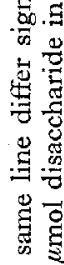

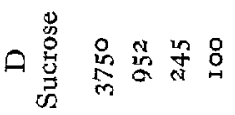

.

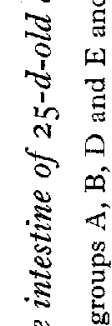

密

为

$\stackrel{5}{\circ}$

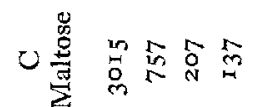

(⿹)

焉

के

:

๓

递密

근

蓥

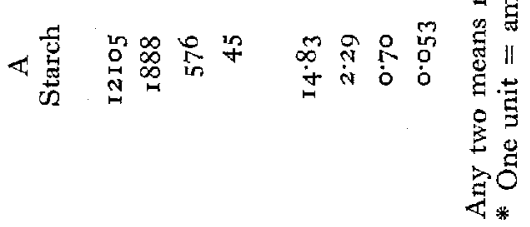

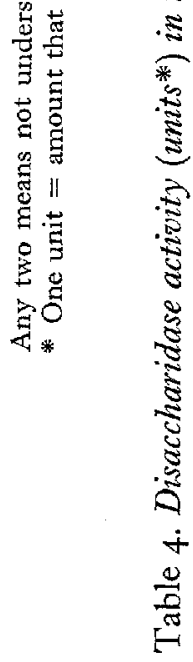

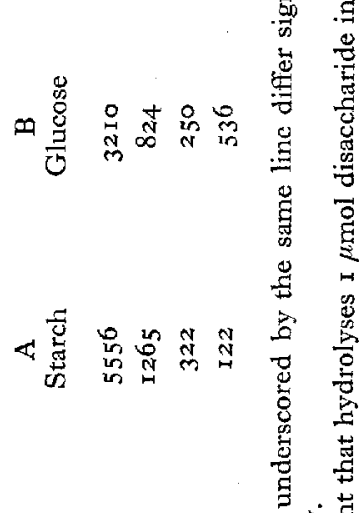

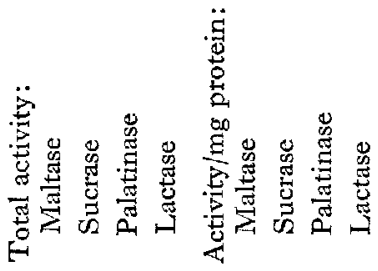

IIn

点

응

단.

居 
The disaccharidase activities in the small intestine of the birds in the different groups are recorded in Table 3, either as total activity or as activity/mg protein. Whichever way the maltasc, sucrase and palatinase activities were expressed, there were no significant differences between the various groups. The total lactase activity was significantly higher in the birds receiving the diet containing lactose than in those given the other carbohydrates. However, this difference disappeared when the activity was expressed per $\mathrm{mg}$ protein.

In the large intestine, the maltase, sucrase and palatinase activities were all higher in the birds receiving the diet containing starch but the difference for maltase only was statistically significant (Table 4 ). The lactase activity in the large intestine was significantly higher in the chicks receiving glucose or $50 \%$ lactose $+50 \%$ glucose than in those given the other carbohydrates. Furthermore, the chicks receiving the $50 \%$ lactose $+50 \%$ glucose had markedly higher lactase activity in the large intestine than those receiving glucose, but owing to the large variation within the groups the difference was not statistically significant.

Table 5. Effect of fasting for $24 h, 48 h$ or $72 h$ on body-weight and the disaccharidase activities in the small intestine of $16-d$-old chicks

\begin{tabular}{|c|c|c|c|c|c|}
\hline \multicolumn{6}{|c|}{ (Mean values for five birds) } \\
\hline & $\begin{array}{c}A \\
(24 h)\end{array}$ & $\begin{array}{c}\text { B } \\
(48 \mathrm{~h})\end{array}$ & $\begin{array}{c}\mathrm{C} \\
\left(7^{2} \mathrm{~h}\right)\end{array}$ & $\begin{array}{l}\text { SE of mean } \\
\text { (I } 2 \mathrm{df})\end{array}$ & Significance \\
\hline Body-wt (g) & I3I & II 7 & II 2 & $7 \cdot 6$ & C B A \\
\hline $\begin{array}{l}\text { Small intestine } \\
\text { protein }(\mathrm{mg} / \mathrm{ml})\end{array}$ & $4 \cdot 13$ & $4 \cdot 28$ & $3 \cdot 18$ & $0 \cdot 16$ & $\overline{\mathrm{CAB}}$ \\
\hline \multicolumn{5}{|c|}{ Total activity (units*): } & C B A \\
\hline Sucrase & I $3 \times 9$ & II 35 & 793 & I39 & $\overline{\mathrm{C} \overline{\mathrm{BA}}}$ \\
\hline Isomaltase & $\operatorname{II} 31$ & $98 z$ & 725 & II 3 & $\overline{\mathrm{C}} \overline{\mathrm{BA}}$ \\
\hline Palatinase & 294 & 231 & 147 & 32 & $\overline{\mathrm{C} \overline{\mathrm{BA}}}$ \\
\hline \multicolumn{6}{|c|}{ Activity/mg protein (units*): } \\
\hline Maltase & $16 \cdot 45$ & 14.06 & $13 \cdot 65$ & $I \cdot 92$ & C B A \\
\hline Sucrase & 3.24 & $2 \cdot 63$ & $2 \cdot 56$ & 0.38 & $\overline{\mathrm{CBA}}$ \\
\hline Isomaltase & $2 \cdot 77$ & $2 \cdot 28$ & $2 \cdot 34$ & $0.3 \mathrm{I}$ & $\overline{\mathrm{BCA}}$ \\
\hline Palatinase & 0.72 & 0.53 & 0.49 & 0.09 & $\overline{\mathrm{CBA}}$ \\
\hline
\end{tabular}

Any pair of means not underscored by the same line differ significantly at the $5 \%$ level of probability. * One unit $=$ amount that hydrolyses $\mathrm{x} \mu \mathrm{mol}$ disaccharide in $60 \mathrm{~min}$ at $37^{\circ}$.

\section{Expt 2}

The effect of fasting on the body-weight and disaccharidase activity in the small intestine is shown in Table 5. Birds that had been fasted for $7^{2} \mathrm{~h}$ tended to have lower body-weights than those that had been fasted for $48 \mathrm{~h}$, which in turn had lower bodyweights than those fasted for $24 \mathrm{~h}$. The differences, however, were not significant. The total activities of all the disaccharidases were significantly lower in the small intestine of chicks fasted for $72 \mathrm{~h}$ than in those fasted for $24 \mathrm{~h}$, with the group fasted for $48 \mathrm{~h}$ being intermediate. This decrease in disaccharidase activity with duration of 
Vol. 27

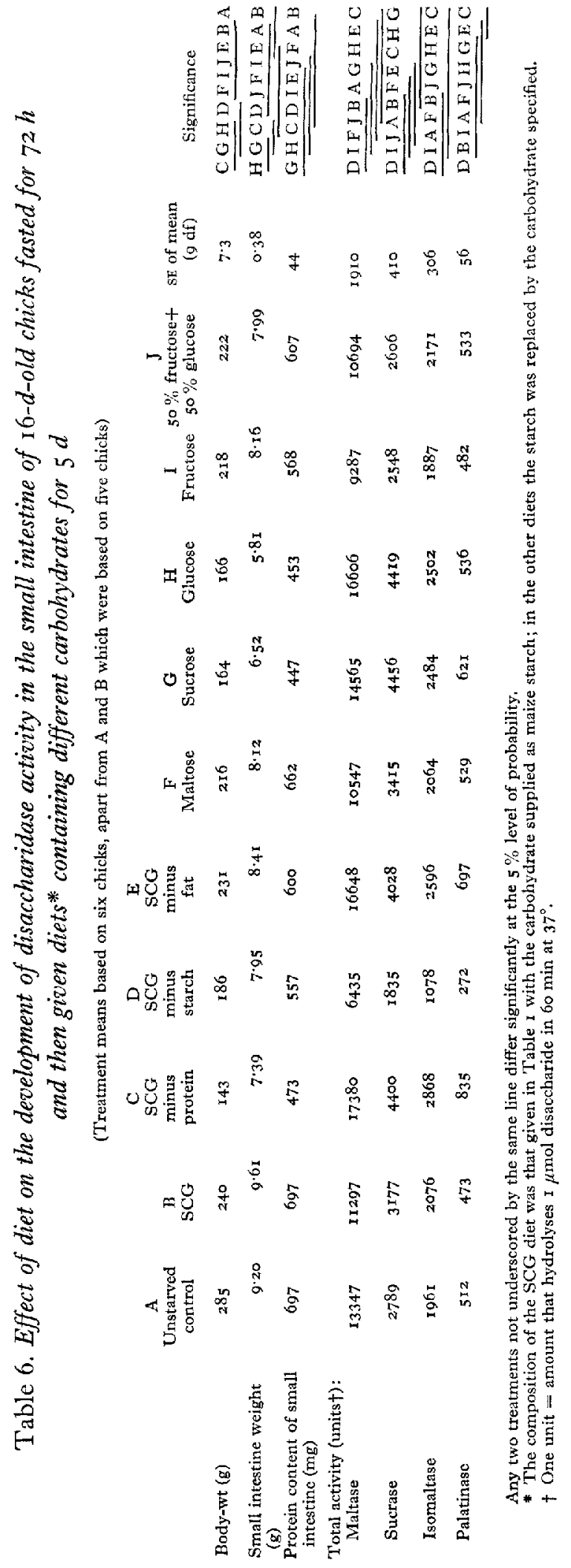


fasting was accompanied by a decrease in the protein content of the small-intestinal homogenates. When the activities were expressed per mg protein, although they still decreased as the length of the fasting period increased, the differences between the groups were no longer significant.

\section{Expt 3}

Table 6 shows the mean values for the body-weights and disaccharidase activitics in the small intestine of groups of chicks which had been fasted for $7^{2} \mathrm{~h}$ and then given different diets for $5 \mathrm{~d}$. In general, the four enzymes studied all responded similarly to a particular diet. No particular diet markedly affected one enzyme more than the other enzymes. Compared with the 'standard diet' the chicks receiving the protein-free diet did not grow well but the levels of disaccharidase activity in their small intestines were higher. The chicks on the fat-free diet grew well and the levels of disaccharidase activity were similar to those of the chicks on the protein-free dict. The disaccharidase activity in the small intestine of the chicks given the carbohydrate-free diet was much lower than in any other group. The chicks receiving glucose or sucrose tended to have higher levels of disaccharidase than those receiving maltose or fructose or a mixture of fructose and glucose.

\section{DISCUSSION}

In the rat and in man it has been shown that diet can affect disaccharidase activity. Knudsen, Bradley, Lecocq, Bellamy \& Welsh (1968) found that, in man, fasting caused a decrease in disaccharidase activity. Refeeding with carbohydrate caused a marked increase in the maltase and sucrase activities, whereas refeeding with fat had no effect. Rosensweig \& Herman (1969) confirmed these observations and concluded that dietary carbohydrate is necessary to alter disaccharidase activity. Furthermore they found that sucrose and fructose exerted a specific effect on development of disaccharidase activity, since feeding with either of these sugars increased maltase and sucrase activities to a greater extent than feeding with glucose, galactose, lactose or maltose (Rosensweig \& Herman, I968a).

It has also been found that diets containing carbohydrate, as compared with carbohydrate-free diets, significantly increase maltase and sucrase activities in the small intestine of the rat (Blair, Yakimets \& Tuba, I963; Deren et al. 1967). However, unlike the effect in man, sucrose had a specific effect on sucrase activity and maltose on maltase activity. Reddy et al. (1968), from a study with germ-free rats, concluded that the specific effect of dietary carbohydrate on intestinal disaccharidase activity occurred independently of the intestinal microflora.

Dietary protein does not appear to play an important part in the regulation of intestinal disaccharidases. No decrease was observed in the activity of intestinal disaccharidases of rats given either low-protein or protein-free diets for a period of $45 \mathrm{~d}$ (Solimano, Burgess \& Levin, 1967; Prosper, Murray \& Kern, 1968). Similarly, in man, protein deprivation for ro d did not alter disaccharidase activity (Rosensweig $\&$ Herman, 19686 ). In patients suffering from kwashiorkor, disaccharide intolerance and reduced disaccharidase activities have been found (Cevini, Giovannini \& Careddu, 1962; Stanfield, Hutt \& Tunnicliffe, 1965). It would appear that though protein 
deprivation for relatively short periods does not affect disaccharidase activity, protein deprivation for longer periods may cause a decrease in activity. However, the possibility that intestinal infection in kwashiorkor may be a contributory cause of the reduced disaccharidase activity should be considered.

The results obtained in this study with the chick show certain similarities to the findings in the rat and man. Fasting resulted in a decrease in both disaccharidase activity and the protein content of the small intestine. Refeeding with a protein-free diet for $5 \mathrm{~d}$ did not affect the development of disaccharidase activity. In fact the smallintestinal homogenates of chicks given a protein-free diet had a lower protein content and therefore, in terms of specific activity (units/mg protein), higher levels of activity than those of chicks receiving a diet containing protein. This would suggest that, during protein deprivation for a short period of time, the endogenous protein is sufficient to allow normal development of disaccharidase activity. The feeding of a fat-free diet to chicks previously fasted did not affect the development of disaccharidase activity, whereas the feeding of a carbohydrate-free diet resulted in much lower levels of disaccharidase activity. In the chick, as in the rat and man, it would appear that dietary carbohydrate is required for the normal development of disaccharidase activity.

In the chick, it was not possible to demonstrate that a particular dietary sugar had a specific effect on small-intestinal disaccharidase activity.

Since sucrose and fructose have a specific effect on maltase and sucrase activity in man, and maltose and sucrose have specific effects in the rat, there may be a difference between species in the response of the disaccharidases to dietary carbohydrate. However, it is possible that the basic mechanism whereby dietary carbohydrate affects disaccharidase activity is similar in all three species. Rosensweig \& Herman (I969) postulated that, since in fasted patients disaccharidase activity in the small intestine never falls to zero, glucose obtained via the blood-stream may operate in maintaining base-line levels. Knudsen et al. (1968) found that glucose injected intravenously had an effect similar to that of dietary glucose in increasing the disaccharidase activity of fasted patients. It is possible that dietary sugar exerts its effect on disaccharidase activity via the blood-stream, i.e. an increase in concentration of blood glucose causes an increase in disaccharidase activity. A difference between species may exist regarding additional mechanisms for increasing disaccharidase activity.

As stated previously, most attempts to show an adaptive increase in lactase activity have been unsuccessful. In the mammalian small intestine there are two $\beta$-galactosidases; one is a heterogalactosidase which has an optimum activity at $\mathrm{pH}_{3-4}$ but does not participate in digestion; the other is specific for lactose and has an optimum $\mathrm{pH}$ 5-6 (Koldovský \& Chytil, 1965; Asp \& Dahlqvist, 1968; Gray \& Santiago, 1969; Gray, Santiago, Colver \& Genel, 1969). The $\mathrm{pH}$ optimum of the chick small-intestinal lactase is $\mathrm{pH}_{3} .6$ and probably corresponds to the heterogalactosidase found in mammals (Siddons, I969). Therefore the chick is considered unsuitable for studying the effect of diet on lactase activity in the small intestine. The higher lactase activity which was found in the small intestine of chicks given a diet containing lactose (Table 3 ) may be an adaptation effect but is probably due to the presence of 
micro-organisms that hydrolyse lactose in the lower part of the small intestine. My experiment was carried out to determine the effect of dietary lactose on the lactose activity in the large intestine. Previous studies (Siddons, 1969) had suggested that the lactase activity in the large intestine of the chick was of bacterial origin and could be induced by dietary lactose. That the latter fact is true is shown by the higher levels of lactase activity in the large intestine of chicks receiving a diet containing lactose (Table 4). Subsequent studies with germ-free chicks have shown that this lactase activity is of bacterial origin and that on a diet in which the sole carbohydrate is lactose its presence is essential for the survival of the chicks (Siddons \& Coates, 1972).

I thank Dr M. E. Coates and Mr G. F. Harrison for their interest and help, $\mathrm{Mr} \mathrm{M}$. Buckland for care and management of the experimental birds, Mr R. J. Merry for technical assistance and Mr M. R. Jones for statistical analysis of the results.

\section{REFERENCES}

Alvarez, A. \& Sas, J. (196r). Nature, Lond. rgo, 826 .

Asp, N. G. \& Dahlqvist, A. (I968). Biochem. F. 106, 84 I.

Bayless, T. M. \& Huang, S. (1969). Am. F. clin. Nutr. 22, 250.

Blair, D. G. R., Yakimets, W. \& Tuba, J. (I963). Can. J. Biochem. 4r, 917.

Bolin, T. D., Pirola, R. C. \& Davis, A. E. (1969). Gastroenterology 57, 406.

Cevini, G., Giovannini, M. \& Careddu, P. (1962). Minerva paediat. 14, 83 I.

Cuatrecasas, P., Lockwood, D. H. \& Caidwell, J. R. (1965). Lancet i, r4.

Dahlquist, A. (1964). Analyt. Biochem. 7, 18.

Deren, J. J., Broitman, S. A. \& Zamcheck, N. (1967). F. clin. Invest 46, 186.

Doell, R. G. \& Kretchmer, N. (r,66). Biochim. biophys. Acta 62, 353.

Gray, G. M. \& Santiago, N. A. (1969). \%. clin. Invest. 48, 7ı6.

Gray, G. M., Santiago, N. A., Colver, E. H. \& Genel, M. (1969). F. clin. Invest. 48, 729.

Keusch, G. T., 'Troncale, F. J., Thavaramara, B., Prinyanont, P., Anderson, P. R. \& Bhamarapravathi, N. (1969). Am. F. clin. Nutr. 22, 638 .

Knudsen, K. B., Bradley, E. M., Lecocq, F. R., Bellamy, H. M. \& Welsh, J. D. (rg68). Gastroenterology $\mathbf{5 5}, 46$.

Koldovský, O. \& Chytil, F. (1965). Biochem. F. 94, 266.

.Lowry, O. H., Rosebrough, N. J., Farr, A. L. \& Randall, R. J. (1951). F. biol. Chem. 193, 265.

Prosper, J., Murray, R. L. \& Kern, F. (I968). Gastroenterology 55, 223.

Reddy, B. S., Pleasants, J. R. \& Wostmann, B. S. (1968). F. Nutr. 95, 4 I 3.

Rosensweig, N. S. \& Herman, R. H. (1968 a). F. clin. Invest. 47, 2253.

Rosensweig, N. S. \& Iterman, R. H. (1968 b). Am. 7 . clin. Nutr. 2r, 536.

Rosensweig, N. S. \& Herman, R. H. (1969). Am. F. clin. Nutr. 22, 99.

Rubino, A., Zimbalatti, F. \& Auricchio, S. (1964). Biochim. biophys. Acta 92, 305.

Siddons, R. C. (1969). Biochem. F. 112, 5 x.

Siddons, R. C. (1970). Biochem. F. 116, 7I.

Siddons, R. C. \& Coates, M. E. (1972). Br. F. Nutr. 27, гог.

Solimano, G., Burgess, E. A. \& Levin, B. (I967). Br. F. Nutr. 2I, 55.

Stanfield, J. P., Hutt, M. S. R. \& Tunnicliffe, R. (I965). Lancet ii, 5 I 9.

Welsh, J. D. \& Walker, A. (1965). Proc. Soc. exp. Biol. Med. r20, 525. 